Tokyo Vernacular 
This page intentionally left blank 


\section{Tokyo Vernacular}

Common Spaces, Local Histories, Found Objects

\section{Jordan Sand}

甲

UNIVERSITY OF CALIFORNIA PRESS

Berkeley • Los Angeles • London 
University of California Press, one of the most distinguished university presses in the United States, enriches lives around the world by advancing scholarship in the humanities, social sciences, and natural sciences. Its activities are supported by the UC Press Foundation and by philanthropic contributions from individuals and institutions. For more information, visit www.ucpress.edu.

University of California Press

Berkeley and Los Angeles, California

University of California Press, Ltd.

London, England

(C) $20 \mathrm{I}_{3}$ by The Regents of the University of California

Library of Congress Cataloging-in-Publication Data

Sand, Jordan, I960-.

Tokyo vernacular : common spaces, local histories, found objects / Jordan Sand.

pages $\mathrm{cm}$

Includes bibliographical references and index.

ISBN 978-0-520-27566-9 (cloth : alk. paper)ISBN 978-0-520-28037-3 (pbk. : alk. paper)

I. Tokyo (Japan)-History-I945- 2. Historic preservation-Japan-Tokyo-History-2oth century. 3. Historic buildings-Conservation and restoration-Japan-Tokyo-History-2oth century. 4. Architecture-Government policyJapan-Tokyo-History-2oth century. I. Title. DS896.66.S26 20I3 $952^{\prime}$. I $3504-\mathrm{dc} 23$

2013013266

Manufactured in the United States of America

$\begin{array}{lllllllllll}22 & 2 \text { I } & 20 & \text { I9 } & \text { I8 } & \text { I7 } & \text { I6 } & \text { I5 } & \text { I4 } & \text { I3 } \\ \text { IO } & 9 & 8 & 7 & 6 & 5 & 4 & 3 & 2 & \text { I } & \end{array}$

In keeping with a commitment to support environmentally responsible and sustainable printing practices, UC Press has printed this book on Rolland Enviroı०o, a Iо०\% post-consumer fiber paper that is FSC certified, deinked, processed chlorine-free, and manufactured with renewable biogas energy. It is acid-free and EcoLogo certified. 
For $M, O$, and $Y$

Friendship would seem to hold cities together.

-Aristotle, Nicomachean Ethics 
This page intentionally left blank 